Research

\title{
Fintech and Its Challenge for Banking Sector
}

\author{
Diyan Lestari ${ }^{1}$, Basuki Toto Rahmanto ${ }^{2}$ \\ Institut Teknologi dan Binis Kalbis, \\ 1)diyan.lestari@kalbis.ac.id ; ${ }^{2}$ basuki.rahmanto@kalbis.ac.id \\ * Corresponding author
}

Received: April 28, 2021; Accepted: June 28, 2021; Published: June 30, 2021

To cite this article: Lestari, D. \& Rahmanto, B.T.(2021). Fintech and its challenge for banking sector, The Management Journal of BINANIAGA, 6(1), 55-70. doi: 10.33062/mjb.v6i1.428

\begin{abstract}
The rapid development of technology has shifted consumer behavior which impact on business, including banking sector. It is expected that technology can be optimized to improve productivity and performance. In banking sector, technology plays important role to ease the financial transaction and minimize cost. In the digital age, most of individual activities are conducted by technology, including completing their financial transaction. Technology also helps to promote financial inclusion. Furthermore, the Covid-19 pandemic has leveraged the digital adoption into different level due to the social distancing practice. This study aims to investigate the fintech strategy to enter the financial service sector, and how bank response the fintech development. This study is a qualitative research which implemented depth interviews and content analysis. Moreover, this paper utilized both primary and secondary data in order to provide valid investigation. This study found that fintech is basically innovative, and promotes innovative strategy to enter the financial service industry, while banks have already prepared to compete in the digital age. Several strategies were formulated by banks to win the competition, including investing in software, hardware, and even in financial technology companies.
\end{abstract}

Kata kunci: fintech, banking, innovation

\section{INTRODUCTION}

Technological tools and apps has shifted consumer behavior which was begun by the simple practical used, for example the ease of online shopping, including purchasing of travel tickets which seems were impossible in the past. The digital adoption has increased significantly and drove the financial technology development. In Indonesia, financial technology or "fintech" has developed rapidly since 2010 which was in line with the fast development of infrastructure and the launching of "Indonesia Digital Economy 2020" (Imam, 2018). In 2017, 1.7 billion adults were not able to gain access to financial institution (bank and non bank institution) and they found difficulty in accessing financial technology. However, according to Demirgüç-Kunt \& et. (2018), developing countries are center of fintech development, especially in Bangladesh, China, India, Indonesia, Mexico, Nigeria, and Pakistan which should be optimized to improve economic growth. In general, there is a huge potential of fintech optimization since there was a slight shifting in financial inclusion from 2010 to 2017 which was only accounted for 0.5 billion adults. The number showed the financial inclusion was relatively slow.

During the Covid-19 pandemic, fintech and digital adoption has experienced significant growth since it is important to acess affordable financial service under the social distancing regulation, reduce the face-to-face interaction while enable the economic activities (World Bank, 2020). In the beginning of 2021, many banks have transform into digital banking based (neobank) or built neobank as new business unit

Diyan Lestari and Basuki Toto Rahmanto. Fintech and its challenge for banking sector 
which represent higher degree of competition in financial sector, it is also suggested that banks should prepare to optimize technology utilization (CNBC Indonesia, 2021). In general, banks play important role in economy while fintech promotes individual financial inclusion by providing efficient financial services. The easier access of financial services will allow individual to manage their money, including income, expenditure, saving, and investment. Higher level of access on financial services also reflect financial inclusion which provide essential indicators to improve society prosperity (Saputro \& Lestari, 2019). Moreover, tradtitional financial service is perceived as expensive instrument to improve financial inclusion since it is required large funds to prove financial service in a region whereas fintech allows society to have better access of financial services and projected to be the largest disruptor in financial sector (Ali, Abdullah, \& Zaini, 2019; Anikina \& et. al., 2016)).

The rapid development of fintech is supported by innovative business model. In 2018, global fintech financing annouced the large number of fintech funding which accounted for $\$ 39$ billion in 2018 and only $\$ 18$ billion in 2017 while Asia found to be region with the highest griwth of fintech funding (265\%) (CB Insight, 2019). Moreover, financial sector is considered as high regulated sector, especially related to interest rate, capital requirements, etc and it will be a competitive market since Google, Tesco, Apple, Samsung, and other companies which also expand their business in financial service sector with a technological-based (Gerstner, 2016). According to Demirgüç-Kunt \& et. (2018), $76 \%$ of $52 \%$ of adults have experienced using the digital payment. Figure 1 exhibits the using of digital payment in the world which also explains the increasing number of digital payment users from 2014-2017.

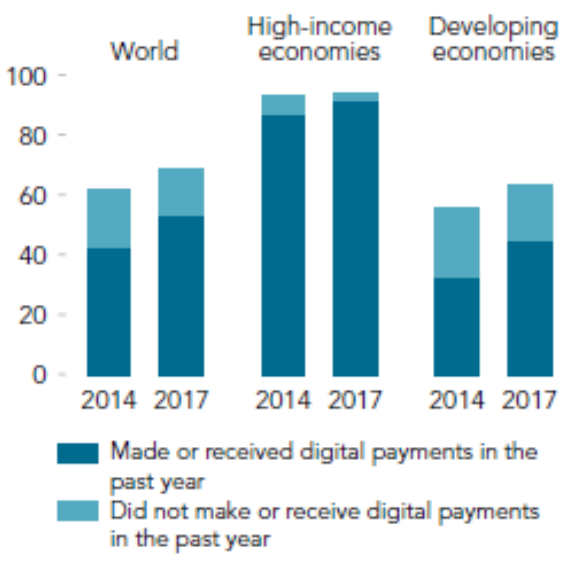

Figure 1 Digital Payment Trend

Source: Demirgüç-Kunt \& et. (2018)

This paper aims to analyze the fintech strategy to enter the financial service sector and how banks response the financial technology movement in the digital era since the fierce competition required banks and fintech to become more innovative. According to EY (2017), fintech core business is payment, financial transaction, and lending. However, banks also optimize the use of technology, including artificial intelligence in most of banks supply chain to improve their services and productivity. Moreover, according to Kontan (2019), most of banks in Indonesia have decided to reduced their branch and in July 2019 there were 466 reduction of banks branch and utilize their digital banking. In general, fintech is relatively new with significant development which provides both challenges and opportunties. This study provides several contributions, firstly this study provides compelementary finding for the existing literature on fintech and banking. Secondly, this paper also highlight the fintech and banks strategy by conducting interviews from users

Diyan Lestari and Basuki Toto Rahmanto. Fintech and its challenge for banking sector 
both fintech and banks to provide better understanding in analyzing fintech and banks strategy.

\section{REVIEW OF LITERATURE}

\section{Financial Intermediation Theory}

Financial intermediation theory modern examined the main role of financial intermediary and regulatory impact on financial intermediation. Moreover, it is also analyzed the intermediary role on economic growth, and supervisory policy impact. The financial intermediary theory was developed at the beginning of 1960s which is based on informational asymmetry theory and agency theory (Adries, 2009). Allen \& Santomero (1998) stated that intermediary provides two different role, as risk transfer facilitator and financial market instrument. Financial intermediation theory which based on intermediation activities is implemented not only for banks but also for other institution that conduct intermediary activities (Werner, 2015). Furthermore, intermediation theory explained the role of banks as liduidity intermediation, risk intermediation, and information intermediation (Servigny \& Renault, 2004). Information intermediation is basically intermediary function to reduce the assymetric information (Freimanis \& Senfelde, 2019; Mitchell, 2005; (Rodrigues \& Galdi, 2017).

\section{Financial Technology in Indonesia}

Financial technology or fintech is a platform in financial services with a digital based. Fintech has developed so fast in Indonesia and most of countries in the world. For instance, in China, Ant Financial (Alibaba Group) and Tencent have gained popularity and have massive users; in Africa, Mesir and India, fintech is important platform to complete transaction (Frost \& et. al., 2019). Fintech, basically possess unique strategy which their basic service is payment, then expand their services on lending, insurance, saving, and investment. In Indonesia, fintech is relatively new and started to gain its popularity in 2010s since the rapid development of technology, including internet, and smartphone. Indonesia is one of the most populated countries and most of its population is actively access the internet and social media. According to Euromonitor (2017), 170 million Indonesian possess smartphone, 130 million utilize the smartphone to access internet. However, 80 million do not have access to financial institution (bank and nonbank) (Euromonitor, 2017). Those opportunities can be utilized by fintech to improve financial inclusion, reduce cost, and improve efficiency (Iman, 2018; Lestari, 2020). Nuryakin, Aisha, \& Massie (2019) stated that fintech is expected to help society in gaining better access in financial service. In general, fintech can be devided into several groups of services: payment, market supporters, investment and risk management, peer to peer lending, funding, capital provision, and other financial services (Tayibnapis, Wuryaningsih, \& Gora, 2018).

\section{Bank and Financial Institution in the Digital Era}

There will be unlimtless competition in the digital era since there are various new business models which are more innovative, easier, and more simple to use. The traditional banks should innovate and develop services in a digital based. Banks can utilize their mobile banking which is basically financial service in a digital that allow customers access the services everytime and everywhere (Tayibnapis, Wuryaningsih, \& Gora, 2018). Banks should analyze consumer trend and follow the regulation since banking sector is one of the most regulated sectors and it is important to develop financial products that follow regulation. Today, digital revolution has transformed the financial sector which can be important tools to improve customer engagement, provide better experience, allow them to explore more of banks services, more transparent, and provide innovative services. Moreover, digital platform is also enable society to gain better financial inclusion, not only for high middle income household, but also for low middle income household (Friedline, Despard, \& Birkenmaier, 2018). Many organizations have

Diyan Lestari and Basuki Toto Rahmanto. Fintech and its challenge for banking sector 
adopted artificial intelligence (AI) and machine learning (ML), including banks in order to win the competition in the digital age. It is also projected that Al may improve efficiency and by utilizing $\mathrm{Al}$, banks and financial institution can save approximately $\$ 1$ trillion. Furtermore, in 2030 it is projected that traditional financial institution can save about $22 \%$. Today, it is about $40 \%-60 \%$ banks have invested in $\mathrm{Al}$ and planned to increase the number of their investment for the next three years (Virtusa, 2018).

\section{RESEARCH METHOD}

This study is a qualitative research which is basically aims to analyze qualitative data and provide more detail explanation. Moreover, it is important to conduct depth interview which provide detail description from both fintech and banks users in analyzing fintech and banks strategy since it will be more difficult to implement depth interview using the quantitative study. Qualitative study is designed to explore phenomenon, and to capture individual thought, feeling, and interpretation (Given, 2008). This study implements exploratory research design by using inductive thematic analysis approach. In general, inductive thematic analysis is a qualitative research method that is often to be implemented in social study, behavior study, and health sciences. The process of the research approach including extracting data from text, indentify themes of the data, coding, and interprete the content of the theme (Guest, MacQueen, \& Namey, 2012). According to Thomas (2006), the aims of inductive approach is to simplify the raw text to be more simple, establish clear linkages between evaluation and the research goal, to summarize the raw data, and to develop framework from the process structure which is derived from the raw data. In general, the aim of inductive approach is to provide simple procedure that is easy to be used and systematic in order to analyze the qualitative data which can provide reliable and valid research finding.

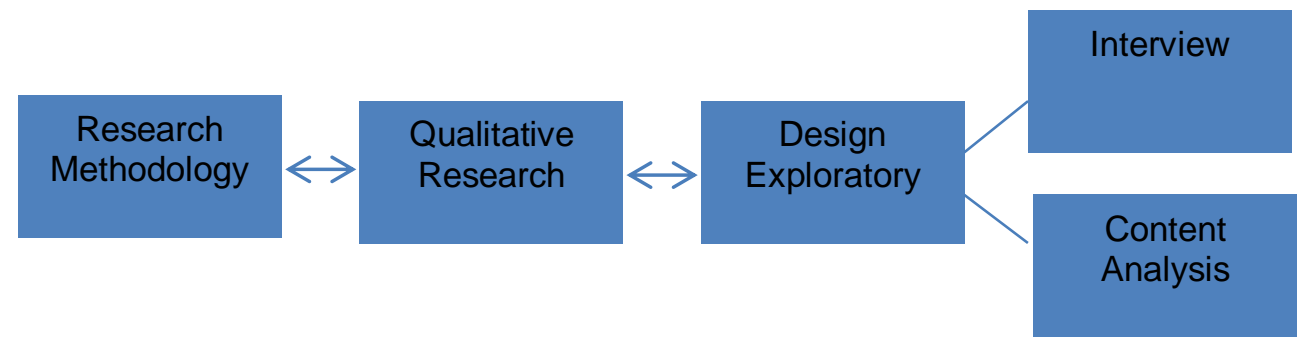

Figure 2 Research Model

Figure 2 explains about the reseach model in this study which describes how this study is conducted by qualitative approach using exploratory design. Moreover, to explore and gain the data, this study employs depth interviews and content analysis, and used gate software to analyze and code the data in order to gain the valid analysis. In qualitative method, the data is collected to gain insight, explanation, and description. Then, the data is analyzed to develop better understanding and narration from many sources and gain insight related to any experience and knowledge of interviewees in a particular topic. Furthermore, to gain and analyze the data, the qualitative study may implement several activities such as, communicate with selected informants, note-taking, and employ literature review from journal, diaries, websites, and other journalistic activities, including video, artworks, and systematical observation. Mason (2002), stated that to collect the data and analyze the qualitative study, it is suggested to observe and create general chategories which represent the expected sources of data. It is also not suggested to develop long and detail chategories. Basically, the general chategories may comprise of various specific and detail sources of data. However, it is allowed to ellaborate data from various chategories, for instance examine a group of individual who

Diyan Lestari and Basuki Toto Rahmanto. Fintech and its challenge for banking sector 
work in an institution and investigate the institution regulation, event, culture, and other aspects.

To gain the insightful data, this study used primary data which is collected by conducting depth interviews and employed secondary data by implementing content analysis. Informant in this study is the big four bank manager in financial sector and the users of both banks and fintech services. Then, this study summarized and analyzed the data by several stages including organize the data, grouping or classifiying, coding, theme development, and other steps that is required to analyze the data. Basically, qualitative study does not employ data population since qualitative study is derived by the pehonemenon or a particular case in certain situation which the result of the study does not be generalized based on its population. Moreover, it is generalized from social situation which has similar social or behavior case. Furthermore, qualitative approach does not poin out the study based on statistical sample representation. Qualitative method usually employs pusposive sampling which indicates the source of data "informant" is selected by several criterias in order to provide meaningful insight and data. It is required a research participant in special category because of his/ her expertise or knowledge since it is important to have credible informant who involve in a particular group and also essential to maximize the sample or informant variation. The next step is to select the demographic variable that provides meaningful impact and insight during the investigation. This study employs purposive sampling technique which required particular criterias, for instance: fintech and bank services user, the big four bank manager, informants should not more than 35 years old and not less than 20 years old since millennial is characterized as tech savy and it is expected they will provide meaningful insight, and informants are fintech and banks customer with minimum 2 for years.

This study implements several methods to collect the data and employs depth interviews and documentation to gain the data. To test the data validity, this study also implements triangulation technique by conducting data checking and data comparison. Moreover, this study uses interactive analysis as data analysis technique which basically comprises of four steps of analysis including: data collection, data reduction, presentation of the data, and conclusion that can be explained as follows:

1. Data collection is collecting the data at the research site by conducting observation, interviews, and documentation. It is employed by formulating data collection strategy which is considered as the most suitable method, determining the research focus, and data analyzing during the process of data collection.

2. Data reduction is selection process, analyzing, abstracting, and transforming the raw data which is gained from the research site and it is conducted by researchers during the data collection. It is continuously process and implemented since the researchers have decided their research focus.

3. Data presentation is a chain of information which allowed the research activities. The data is presented by gaining from various sources, including network, linkages of activities or tables, etc.

4. Conclusion is a process during the data collection which provides suggestion for researchers to be more aware and responsive during the research process by creating the causality patterns.

\section{RESULT AND DISCUSSION}

\section{Informant Characteristic}

Table 1 Informant Characteristic

\begin{tabular}{lrl}
\hline Name & Usia & Pekerjaan \\
\hline \hline C1 & 21 & Student \\
C2 & 22 & Student \\
C3 & 22 & Student
\end{tabular}

Diyan Lestari and Basuki Toto Rahmanto. Fintech and its challenge for banking sector 


\begin{tabular}{lrl}
\hline Name & Usia & Pekerjaan \\
\hline \hline C4 & 23 & Student \\
K1 & 32 & Banker - BCA \\
K2 & 33 & Banker - BRI \\
K3 & 33 & Banker - Mandiri \\
K4 & 33 & Banker - BNI \\
\hline \hline
\end{tabular}

Table 1 shows the informant characteristic which can be divided into two groups. This study classified the informants by two types of user. Both types of user should have experience in using fintech and mobile banking. The first type of user is consumer both of fintech and bank services, while the second type is banker who is in a managerial position from the big four banks companies who also experienced in using both services.

\section{Discussion}

\section{Financial Technology Definition}

This study aims to examine about the fintech strategy and how banks strategy response the competition in the digital era. Most of people define financial technology of fintech as financial services in a technological based. This study conducted depth interviews to gain insight from informants, including about the definition of fintech to analyze the informants understanding about fintech. The result shows that the informants who are users for both fintech and bank financial services defined fintech or financial technology as financial services in a digital and technological based. However, every informants provided various detail description of the fintech definition. Informant (C1) stated described fintech as a tool that facilitates and helps easier financial transaction. Informant (C2) defined fintech as a financial services which provides practical financial services in a digital based. While, informant C3 and C4 also described financial technology as digital financial in a digital and technological based.

In general, informants from banking sector also have similar response related to financial technology definition. They defined fintech or financial technology as a financial service innovation in a technological based. The first informant (K1) explained that fintech helps user to provide better, easier, and innovative financial transaction. Informant (K2) states that fintech is a financial innovation of financial service in a technological based. While informants (K3 and K4) defined fintech as innovative financial services in a technological based that helps banks to provide financial inclusion.

According to the interviews, this study concludes that fintech or financial technology is part of financial service sectors which provides financial services in a digital based. The definition is also has similar description to Demirgüç-Kunt \& et. al. (2018), financial technology or fintech is an innovation in technological based which supports and provides financial services for its users (intermediary service). However, the dynamic of technology development and customer behavior shifting has brought large impact on business. In the past, many activities were conducted manually and offline which required face to face activities. The rapid development of technology has triggered new business model, including Fintech. In general, fintech provides innovation in providing automated financial services which refers to innovative financial services, including how to market the financial product which can be accessed by using smart phone and internet. Fintech can be defined as a platform that provides access for financial services for their users by optimized automated channel.

\section{Fintech Strategy and Financial Service Sector}

Fintech is relatively new in financial service sector and still becomes interesting topic among academics and decision makers about its challenge to banks and other financial institution. How fintech can compete with other financial institution is also interesting to be analyzed. The most important thing to note is services become one of 
the most essential strategies to enter and compete in financial sector. Informant (C1) relatively often uses fintech services and feels so comfortable to use the platform. Informant $(\mathrm{C} 1)$ often uses the service to shop, especially for foods and beverages, and the platform that the informant uses is Gopay and OVO. The main reason is because the platform is practical, simple, and it is connected with Gojek and Grab. Moreover, fintech promotion activities and events are quite interesting, there are many promos, and it is very easy to complete the transaction and register the account is very simple which is can be accomplished by using smartphone and ID. Informant (C2) chose to use fintech because it helped the informant a lot to complete the cashless transaction anytime and anywhere. Financial technology also collaborates with retails, restaurants, hotels, and other places that may provide loan and funding in simple procedures. Other things to point out is fintech promotion activities which quite interesting and creative. Fintech usually promotes its advertising program in social media, especially via YouTube and Instagram in attractive way. Fintech also offers many promotions, including discount, free gifts, and other sales promotions. Moreover, creating new account and registration process is relatively easy which can be completed by downloading fintech application from appstore or playstore and users can easily use to complete the transaction.

Informant C3 stated that completing financial transaction by using financial technology platform is quite easy and informant C3 also often uses the platform, C3 uses the platform at least two times a month. Fintech provides attractive promotion, card-less and cashless transaction also become informant consideration to optimize financial transaction by using fintech. Moreover, fintech often offers attractive sales promotion and collaborates with many retailers, and tenants. While informant C4 prefers to use fintech to complete financial transaction since it is easier, especially to accomplish digital transaction such as Netlix bill, Apple music, and other transactions. Informant C4 also mentions about fintech promotion activities that is attractive, and ease of digital transaction which promotes cashless transactions. Fintech sales promotion also triggers many users to download and use the platform.

In general, informants from another type of user explained that financial technology is part of lifestyle and some people cannot live without the platform. Informant $\mathrm{K} 1$ described that he uses the platform because the platform is easy, practical, and can be utilized to do cashless transaction. The informant also explained that financial technology also provides pleasant impression with their attractive promotion activities. However, the informant also considered that banks services still become important tool to conduct transaction since people need to top up their fintech account by using their bank account. While informant K2 is quite often to use fintech service especially if the services collaborates with other products or services, such as online transport and retailers. Furthermore, the process of registration is quite simple, fast and easy, fintech registration is only required mobile phone number. Informant K2 also points out that fintech will not continually promote many discounts and promos in the future since companies usually start their business by using penetration strategy. After they enter the market and grab their target market, they will adjust their strategy, including promotion strategy. Informant $\mathrm{K} 3$ also often uses fintech platform because it is easy, innovative, and practical. Fintech also collaborates with many outlets, online transport, and many type of tenants. Moreover, fintech often provides attractive promos compare to other services. However, informant $\mathrm{K} 3$ suggests that fintech service is not safe enough because the platform does not required user verification.

Informant K4 also expresses interest in fintech services because it is easy to use, many promos, and it is connected with other platforms. It is also considered as practical and innovative platform. Fintech promotional activities are quite intense, aggressive, broader target market, and innovative. Moreover, mobile banking transaction is also considered as one of important fintech strategy to gain new customers. According those explanation, this study summarizes that financial technology strategy to enter the financial market and competes with banks and other institutions is by providing excellent services from its platform, for instance fintech provides easy, simple, and practical services.

Diyan Lestari and Basuki Toto Rahmanto. Fintech and its challenge for banking sector 
Registration and transaction process are the easiest compare other services, fintech are also innovative companies, they create attractive content in promotion activities, collaborate with retailers, online and offline transport, and provide many promos.

\section{Fintech and Financial Service}

According to CFA Institute (2016), it is possible that in the future there will be many other financial products or services are disrupted by fintech. Moreover, the result of their result showed products or services that can be disrupted are comprised of asset management $(54 \%)$, bank product and/ or services $(16 \%)$, security companies $(12 \%)$, insurance (8\%), financial advisors and wealth management $(7 \%)$, and others $(3 \%)$. Informants in this study are very responsive and love to share their opinion about the possibility of fintech disruption impact on banking sector. This study shows that there will be possibilities of fintech disruption on banking sector and other financial services since fintech is innovative and easy to use.

Informant from user group stated that several banks products or services can be disrupted by fintech, but onlye several part of services. Informant $\mathrm{C} 1$ explaines that some of fintech services may distrupt banks services but not all products or services which provided by banks. For example, the easy process in lending and investment activities will drive many people to use the platform. Informant $\mathrm{C} 2$ also describes similar statement that there will be possibilities for financial technology to disrupt banking sector because of its superior services. While informant $\mathrm{C} 3$ states that he usually allocates small amount of money in fintech application, while he prefers to save his money in banks account including in completing financial transaction. Informant C4 says that financial technology will disrupt banks if banks do not innovate or collaborate with fintech companies.

This study also conducted interviews and asked some questions to banker informant about the disruption possibilities. In general, banker informant provided different insight compare to user informant related to disruption. Informant K1 stated that fintech only provided transaction in small plafond compare to banks, while banks were able to provide larger transaction plafond. Informant K1 concludes that it is relatively impossible for fintech to disrupt the banking sector. However, informant K2 and K3 provide different explanation that it will be possible for fintech to disrupt banking sector. According to the interviews, this study concludes that the rapid development of financial technology may disrupt banking sector because of its innovative service. While the level of disruption and how it impacts banking will depend on banks strategy to respond fintech strategy and also the regulation of policy makers.

\section{Banks in the Digital Era}

In 2017, a research company (Finetra) conducted a research to more than 100 professional who work in financial institution. Respondents are comprised of person who are in payment processors, banking, corporate treasuries, merchant services, and industry association. One of the most important to note is banks realize that payment services transformation is very essential in the digital transformation process, but they relatively less confidence about their strategy and how to implement the digital payment (Finextra \& Dovetail, 2017). Moreover, the moderate growth of non-cash transaction which accounted for $11.2 \%$ from $2014-2015$ represented how important the digital transformation implementation (Capgemini Worldwide \& BNP Paribas, 2017).

Banks response in digital era is very critical to formulate banks direction and strategy in the future. This study also provides insight from users in perceiving banks services in the digital age. Informant C1 explained that in general bank services is less innovative and not responsive in responding customer needs by providing easy access in financial services. However, banks are considered as informative institution which provide comprehensive information in many platforms both offline and online. The informant often uses mobile banking and saving account. While informant C2 describes bank services are quite innovative, for instance ATM or automated teller machine enables many customers to withdraw their money without debit or credit card, and they only need to

Diyan Lestari and Basuki Toto Rahmanto. Fintech and its challenge for banking sector 
scan with their smart phone. Mobile banking is also considered as innovative product of banks, it is easy to transfer the money, complete online payment, and other transaction anytime and anywhere. Informant C2 also often uses mobile banking and saving account to complete his transaction.

Informant C3 states that banking services is relatively innovative since banks also start to develop its business in digital based. For instance, Bank Central Asia adds its debit online feature which linkage with is Debit Card to complete payment transaction in many platforms including e-commerce. Banks are also quite informative to provide information in many platforms in social media, call center, and also website. While, informant C4 explains that many of banks services are innovative and quite responsive to provide consumers need and want. Informant C4 often uses mobile banking and ATM.

Interview to bank managers will provide broader insight about what banks have already developed to respond the financial technology challenges. Informant K1 stated that banks have developed many innovative products and services in digital based, and have already provided relevant information about their products and services. The most favorite banking products are mobile banking, internet banking, and e-wallet such as sakuku BCA, QR Code, and other bank products/ services. In general, informant K2, K3, and $\mathrm{K} 4$ also stated that banking sector have become innovative institution, responsive in facing challenge, adaptable in responding dynamic invorenment, and banks also provided detail informantion about their products and services. Mobile banking and internet banking are the most favorite products that they often use.

According to the interviews, we conclude that banks have become very responsive to face the dynamic challenge in financial sector. Banks also develop its business in the technological and digital based to respond the fierce competition, especially from financial technology. The most important to note is innovation, responsiveness, and continually develop banks products/ services in digital/ technological base to compete in the digital era.

\section{Bank Financial Report}

Table 2 Bank Summary Strategy

\begin{tabular}{|c|c|c|c|c|c|}
\hline NO & NAMA BANK & \multicolumn{4}{|c|}{ Bank Summary Strategy (Q1 2020) } \\
\hline \multirow{16}{*}{1} & \multirow{16}{*}{$\begin{array}{c}\text { PT Bank } \\
\text { Mandiri Tbk. }\end{array}$} & \multicolumn{4}{|c|}{ Technology, SMS banking, Internet Banking, Mobile Banking, Phone Banking } \\
\hline & & \multicolumn{4}{|l|}{ ATM } \\
\hline & & \multirow{4}{*}{ Fintech } & Investment & Type of Business & $\begin{array}{c}\% \text { of } \\
\text { Ownership }\end{array}$ \\
\hline & & & PT Fintek Karya Nusantara & Fintech Lending & $17.03 \%$ \\
\hline & & & PT Amartha Mikro & Fintek Fintech Lending & $9.45 \%$ \\
\hline & & & PT Investree Radhika Jaya & Fintech Lending & $2.62 \%$ \\
\hline & & \multirow{2}{*}{ Digital } & PT Privy Identitas Digital & Digital Service & $10.00 \%$ \\
\hline & & & $\begin{array}{l}\text { PT Cashlez Worldwide } \\
\text { Indonesia }\end{array}$ & Mobile point of sale & $10.00 \%$ \\
\hline & & \multicolumn{4}{|c|}{ Software } \\
\hline & & \multicolumn{4}{|c|}{ Information \& Technology System Group } \\
\hline & & \multicolumn{4}{|c|}{ Information Technology } \\
\hline & & \multicolumn{4}{|c|}{ Efficiency } \\
\hline & & \multirow{4}{*}{$\begin{array}{l}\text { Board } \\
\text { of } \\
\text { Diector }\end{array}$} & \multicolumn{3}{|l|}{ President Director } \\
\hline & & & \multicolumn{3}{|l|}{ Vice President Director } \\
\hline & & & \multicolumn{3}{|c|}{ Director of Consumer and Retail Transaction } \\
\hline & & & \multicolumn{3}{|l|}{ Director of Risk Management } \\
\hline
\end{tabular}

Diyan Lestari and Basuki Toto Rahmanto. Fintech and its challenge for banking sector 
The Management Journal of BINANIAGA Vol. 06, No. 01, June 2021

p-ISSN: 2527-4317, e-ISSN: $2580-149 x$

$6^{\text {th }}$ Accreditation Rating: April 04, $2019-$ April 03, 2024

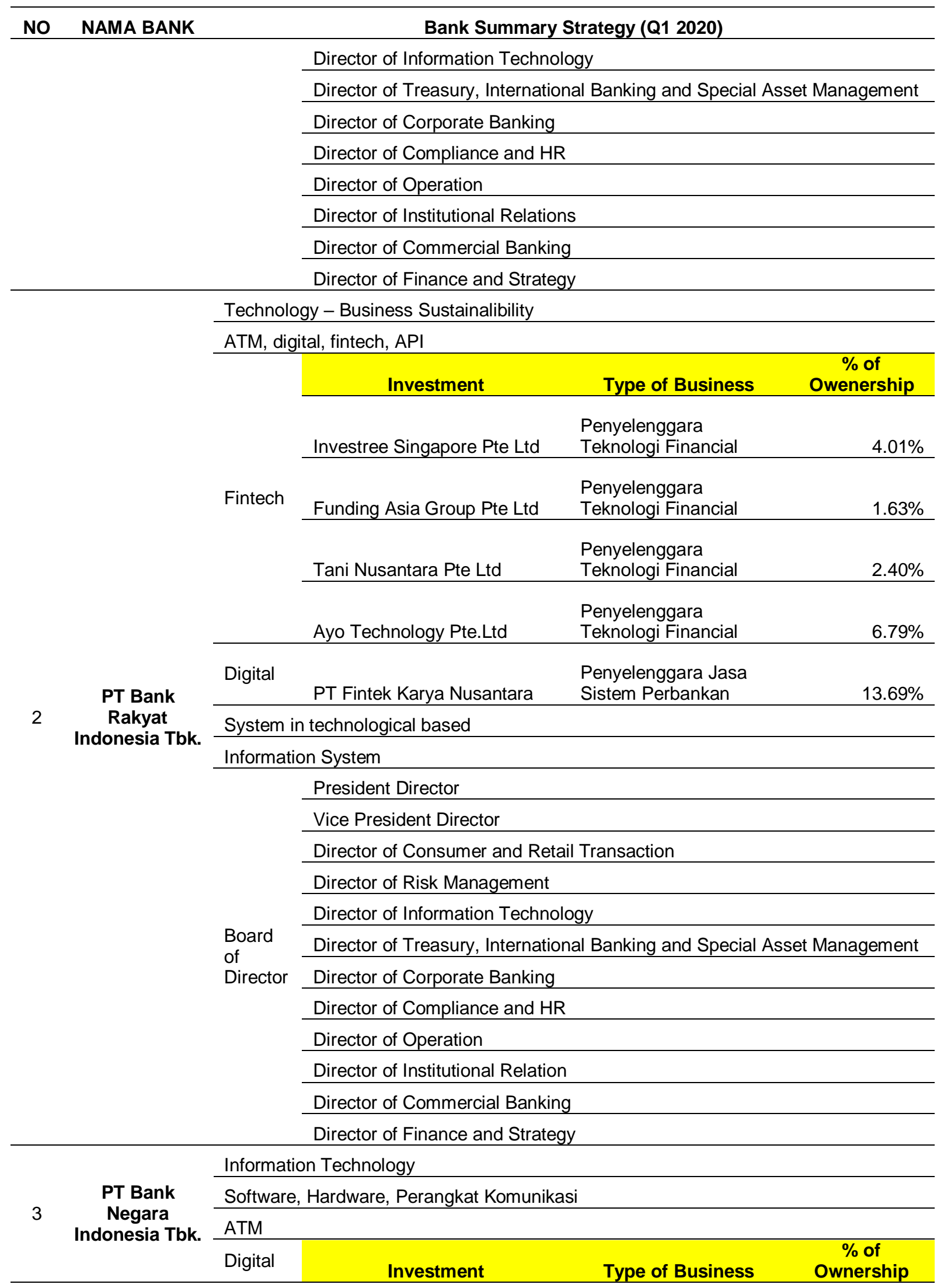

Diyan Lestari and Basuki Toto Rahmanto. Fintech and its challenge for banking sector 
The Management Journal of BINANIAGA Vol. 06, No. 01, June 2021

p-ISSN: $2527-4317$, e-ISSN: $2580-149 x$

$6^{\text {th }}$ Accreditation Rating: April 04, 2019-April 03, 2024

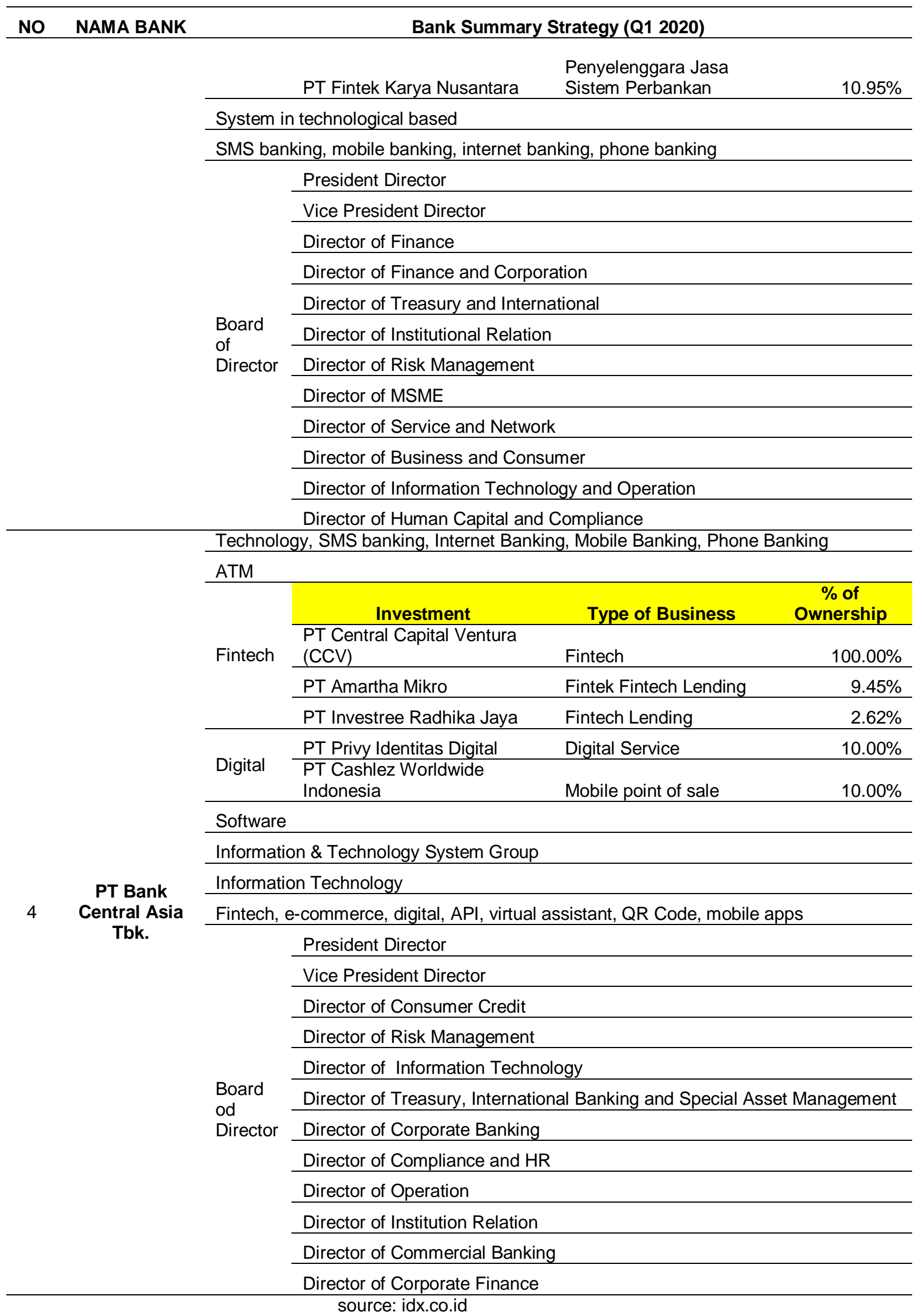

Diyan Lestari and Basuki Toto Rahmanto. Fintech and its challenge for banking sector 
Table 2 shows explanation which is analyzed by using financial statement of the big four bank companies, including PT Bank Mandiri Tbk., PT Bank Negara Indonesia Tbk., PT Bank Rakyat Indonesia Tbk., dan PT Bank Central Asia Tbk. The table basically describes banks strategy to compete in the digital era, including how to compete with financial technology platform and other digital services. In general, the big four bank companies strategies are relatively similar, all of them pay big attention and concern to develop information technology and digital services which can be represented by budget allocation in sofware, and information technology system. Moreover, they also invest in companies which their busines is in technological based including fintech and digital companies. PT Bank Central Asia Tbk also invests to develop its new financial technology firm with $100 \%$ of ownership.

Corporate governance plays important role to help companies in monitoring, supervisory, directing, and determining companies long term vision. On of the most important part of corporate governance is owenership structure which will determine firm control and supervision. Ownerhsip in fintech companies shows that banks have already invested their money as part of their strategy in digital era. The data shows some bank companies do not possess high proportion of ownership (three of four bank companies possess less than $20 \%$ of ownership). However, this study highlights the bank investment strategy which represents bank willingness to take part in fintech business and ownership in fintech companies is one of their biggest steps. Moreover, another bank strategy can be showed by bank board of director which also represents bank monitoring, and supervisory activities. The data illustrates that bank companies have already formulated digital strategy which represented by the role of directors. The important thing to note is, directors will help bank to monitor and formulate bank strategy to compete in the digital era.

\section{CONCLUSION AND RECOMMENDATION}

The rapid development of technology has driven companies to manage their business in the technological based. Financial technology is one of innovative companies which provides financial products/ services in digital based. Fintech strategy to enter and compete in financial sector is basically simple, the automated financial service which is easy, simple, and practical are become fintech main strategy and become essential feature for users to use fintech in their daily life. Moreover, fintech companies also innovate to create attractive promotion activities, including promo program, discount, coupon, and collaboration with many tenants, retailers, transport service providers, and others.

Financial technology has grabbed a lot of attention from society and the presence of fintech has given impact on financial sector, especially banking industry. Fintech is perceived as innovative companies which provides innovative products/ services and is projected to disrupt banking sector. However, fintech services' ability to provide financial services is relatively limited and banks still provide important role in economy as intermediary institution. Fintech disruption impact on banking sector is still widely debated and the disruption will also depend on how banks strategy to respond fintech strategy and regulatory policies.

This study concludes that banks basically has formulated innovative strategy to compete in the digital era and are very responsive to meet the challenges of other innovative companies, especially financial technology companies. Banks products/ services are also considered as innovative, such as ATM, mobile banking, internet banking, and e-money. Other bank strategies are investment strategy and bank corporate governance, including bank investment strategy in fintech companies and bank monitoring system which is represented by the board of director.

Diyan Lestari and Basuki Toto Rahmanto. Fintech and its challenge for banking sector 


\section{REFERENCES}

Adries, A. M. (2009). Theories Regarding Financial Intermediation and Financial Intermediaries - A Survey. The Annals of The "Ştefan cel Mare Vol. 9, No. 2, (10), 254-261.

Ali, H., Abdullah, R., \& Zaini, M. (2019). Fintech and Its Potential Impact on Islamic Banking and Finance Industry: A Case Study of Brunei Darussalam and Malaysia. International Journal of Islamic Economics and Finance Vol. 2, Issue 1, 73-108.

Allen, F., \& Santomero, A. (1998). The Theory of Financial Intermediation. Journal of Banking \& Finance 21, 1461-1485.

Anikina, I., \& et. al. (2016). Methodological Aspects of Prioritization of Financial Tools for Stimulation of Innovative Activities. European Research Studies Journal, 19 (2), 100-112.

Capgemini Worldwide \& BNP Paribas. (2017). World Payments Report 2017: Developments in the Global Payments Landscape. Capgemini Worldwide \& BNP Paribas.

CB Insight. (2019). 2019 Fintech Trends to Watch. CB Insight.

CFA Institute. (2016). Fintech Survey Report. CFA Institute.

CNBC Indonesia. (2021). Keberadaan Neobank di Indonesia Peluang atau Ancaman? Dipetik March 21, 2021, dari www.cnbcindonesia.com: https://www.cnbcindonesia.com/news/20210226134413-51-226402/keberadaanneobank-di-indonesia-peluang-atau-ancaman

Demirgüç-Kunt, A., \& et. al. (2018). The Global Findex Database 2017: Measuring Financial Inclusion and the Fintech Revolution. World Bank.

Euromonitor. (2017). Mobile Phone in Indonesia. Retrieved November 9, 2019, from www.euromonitor.com: https://www.euromonitor.com/mo-bile-phones-inindonesia/report

EY. (2017). FinTech Adoption Index. EY.

Freimanis, K., \& Senfelde, M. (2019). Credit Creation Theory and Financial Intermediation Theory: Different Insights on Banks" Operations. International Scientific Conference: Contemporary Issues in Business, Management and Economics Engineering 2019, (pp. 324-331). Vilnius, Lithuania.

Friedline, T., Despard, M., \& Birkenmaier, J. (2018). Policy Recommendations for Expanding Access to Banking and Financial Services. Policy Brief No. 11-4.

Frost, J., \& et. al. (n.d.). BigTech and The Changing Structure of Financial Intermediation. BIS Working Papers No. 779.

Gerstner, L. (2016). New Ways to Pay with Your Phone. Kiplinger's Personal Finance.

Diyan Lestari and Basuki Toto Rahmanto. Fintech and its challenge for banking sector 
The Management Journal of BINANIAGA Vol. 06, No. 01, June 2021

p-ISSN: 2527 - 4317, e-ISSN: $2580-149 x$

$6^{\text {th }}$ Accreditation Rating: April 04, 2019 - April 03, 2024

Given, L. M. (2008). The Sage Encyclopedia of Qualitative Research Methods. London:: SAGE Publications, Inc.

Guest, G., MacQueen, K., \& Namey, E. (2012). Applied Thematic Analysis. Thousand Oaks, CA: Sage.

Hartono, B. (2013). Sistem Informasi Manajemen Berbasis Komputer. Jakarta: Rineka Cipta.

Iman, N. (2018). Assessing the Dynamics of Fintech in Indonesia. Investment Management and Financial Innovations, Volume 15, Issue 4, 296-303.

Lestari, D. (2020). Manajemen Keuangan Pribadi Cerdas Mengelola Keuangan. Deepublish.

Mason, J. (2002). Qualitative Researching Second Edition. SAGE Publications.

Mitchell, J. (2005). Financial Intermediation Theory and Implications for The Sources of Value in Structured Finance Markets. NBB Working Paper No. 71.

Mulyani, I., Satria, E., \& Supriatna, A. D. (May 2013). Pengembangan Short Message Service (SMS) Gateway Layanan Informasi Akademik. Jurnal Algoritma, 9(2), 389-397.

Muslihudin, M., \& Oktavianto. (2016). Analisis dan Perancangan Sistem Informasi Menggunakan Model Terstruktur dan UML. Yogyakarta: Andi Offset.

Nuryakin, C., Aisha, L., \& Massie, N. (2019). Financial Technology in Indonesia: A Fragmented Instrument for Financial Inclusion? LPEM-FEB UI Working Paper 036.

O'Brien, \& Marakas. (2013). Management Information System Sixteenth Edition. New York: Mc Graw Hill.

P, K. (2013). Ekologi Industri. Yogyakarta: Andi Offset.

Rodrigues, S., \& Galdi, F. (2017). Investor Relations and Information Asymmetr . USP, São Paulo, Vol. 28, No. 74, 297-312.

Saputro, R. E., \& Lestari, D. (2019). Effect of Financial Literacy and Risk Perception on Student Investment Decisions in Jakarta. Review of Management and Entrepreneurship, Vol 3 No 2.

Servigny, A., \& Renault, O. (2004.). Measuring and Managing Credit Risk. USA. 2004: The McGraw-Hill Companies, Inc.

Sitanggang,L.M.S. (2019). Jumlah Kantor Cabang Bank Makin Menurun, Ini Kata Bankir. Retrieved November 8, 2019, from www.kontan.co.id: www.kontan.co.id: https://keuangan.kontan.co.id/news/jumlah-kantor-cabang-bank-makin-menurunini-kata-bankir

Sukamto, R. A., \& Shalahuddin, M. (2015). Rekayasa Perangkat Lunak Terstruktur dan Berorientasi Objek. Bandung: Informatika.

Diyan Lestari and Basuki Toto Rahmanto. Fintech and its challenge for banking sector 
Tayibnapis, A., Wuryaningsih, L., \& Gora, R. (2018). The Development of Digital Economy in Indonesia. IJMBS Vol. 8, Iss ue 3, 14-18.

Thomas, D. R. (2006). A General Inductive Approach for Analyzing Qualitative Evaluation Data. American Journal of Evaluation, 237-246.

Virtusa. (2018). Al-led Transformation in the Banking and Financial Services Industry. Virtusa Corporation.

Werner, R. A. (2015). A Lost Century in Economics: Three Theories of Banking and The Conclusive Evidence. International Review of Financial Analysis.

World Bank. (2020). Fintech Market Reports Rapid Growth During COVID-19 Pandemic. www.worldbank.org.https://www.worldbank.org/en/news/pressrelease/2020/12/03/fintech-market-reports-rapid-growth-during-covid-19pandemic 
The Management Journal of BINANIAGA Vol. 06, No. 01, June 2021

p-ISSN: 2527-4317, e-ISSN: $2580-149 x$

$6^{\text {th }}$ Accreditation Rating: April 04, 2019 - April 03, 2024

This page intentionally be emptied

Diyan Lestari and Basuki Toto Rahmanto. Fintech and its challenge for banking sector Page : 70 